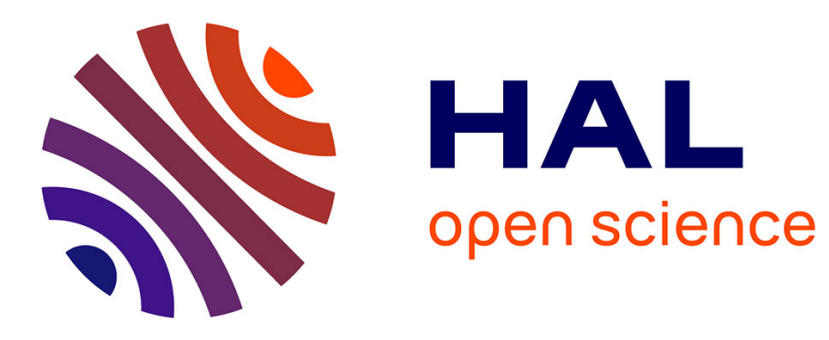

\title{
Drawing the line: how inspectors enact deviant behaviors
}

Jean-Baptiste Suquet

\section{To cite this version:}

Jean-Baptiste Suquet. Drawing the line: how inspectors enact deviant behaviors. Journal of Services Marketing, 2010, The dark side of customer service 24 (6), pp.468-475. hal-01133097

\section{HAL Id: hal-01133097 \\ https://hal.science/hal-01133097}

Submitted on 2 Mar 2016

HAL is a multi-disciplinary open access archive for the deposit and dissemination of scientific research documents, whether they are published or not. The documents may come from teaching and research institutions in France or abroad, or from public or private research centers.
L'archive ouverte pluridisciplinaire HAL, est destinée au dépôt et à la diffusion de documents scientifiques de niveau recherche, publiés ou non, émanant des établissements d'enseignement et de recherche français ou étrangers, des laboratoires publics ou privés. 


\title{
Drawing the line: how inspectors enact deviant behaviors. ${ }^{1}$
}

\author{
Jean-Baptiste Suquet \\ (Reims Management School, Reims, France, and IRG, Université de Paris-Est, Marne-la-Vallée, France)
}

\begin{abstract}
Purpose: the article seeks to show frontline employee sensemaking in service encounters. The purpose is to reveal the processual nature of the dysfunctional behaviour category and to point out the dilemmas that organizations face when drawing the line between what is acceptable and what is not.

Methodology: the article focuses on fare evasion management in urban bus transport, and more specifically on control interactions between ticket inspectors and passengers. Thanks to an ethnographic study of inspection work and to a dramaturgical approach to control interactions, the article accounts for the process of fraud enactment.

Findings: the article gives insight into a specialized service related activity: frontline inspection. It shows how different types of fare evasion behaviours are identified, qualified and eventually enacted. In addition, it points out three types of dilemmas in deviant behaviour management: service / sanction; offense focused perspective / dysfunctional behaviour management perspective and control outcome effectiveness / control outcome visibility.

Research limitations / implications: further research is needed to generalize the results. Moreover this original enactment perspective may not be restricted to service encounters, and future research work should address other aspects of the dysfunctional behaviour enactment process.

Practical implications:

Originality: the paper contributes to the theory of deviant client's behaviours and brings a processual and social-constructive perspective.
\end{abstract}

Keywords Fraud; bus inspectors; control interaction; dysfunctional behaviour; service encounters; enactment.

Paper category Research paper

\footnotetext{
${ }^{1}$ We would like to thank the anonymous reviewers of the article. Their advice was very helpful to make the paper progress.
} 


\section{Introduction}

As recent literature clearly shows growing concern for customer deviant behaviour in service settings, no effort has been made to understand how organizations make sense of the category and enact dysfunctional behaviours. The aim of the study is to show the processual nature of the deviant behaviour category and put the stress on challenges organizations face when enacting deviant behaviour.

This article proposes to explore this enactment perspective by focusing on fraud and control encounters. An ethnographic study of urban bus inspectors' work and a dramaturgical approach to their control encounters enables one to describe the process of fare evasion enactment.

The study brings insights into the organizational process of deviant behaviour enactment. It also shows three organizational dilemmas of this process. Managerial implications are discussed and further research in the same perspective on dysfunctional behaviour is called for.

\section{From consumer misbehaviors to the management of misbehaviors: control work}

\section{Consumers' misbehavior as an organizational issue}

Until recently, few research works focused on the issue of consumers' misbehavior (Fullerton and Punj, 1993; 2004). Yet, since Christopher Lovelock pointed out a specific category of service customers, "jaycustomers" (Lovelock, 1994), more attention has been paid, on the one hand to the motives and forms (Fullerton and Punj, 1993; Cox et alii, 1990; Harris and Reynolds, 2004) and on the other hand to the consequences (Harris and Reynolds, 2003) of deviant customers' behavior.
Indeed, conflicts are likely to emerge between customers and frontline employees in service encounters (Bateson, 1985), and the way the former behaves during these encounters appears to be critical (Harris and Reynolds, 2003).

However, research efforts have been mainly concentrated on the field of consumer research up to now, and we do not know much about the way organizations cope with their difficult customers. On the one hand, a few articles emphasize frontline employees' point of view (Bittner et al., 1994) and tactics (Harris \& Reynolds, 2006); but however interesting and promising this perspective may appear, it remains largely informal.

On the other hand, although executives often misinterpret the customer-orientation of their company (Mason and Harris, 2005), they are nevertheless urged to achieve service excellence and customer orientation (Schneider and McFarlin, 2004; Peccei and Rosenthal, 2001), and the management of deviant customers is certainly not at the top of their agenda.

As a consequence, and with the notable exception of Fullerton and Punj who analyze the effects of deterrence and education on consumers (Fullerton and Punj, 1997), there is a lack of studies on organizational processes aimed at tackling the issue of deviant consumers. This article intends to bring insights into the topic.

\section{The enactment of dysfunctional behaviors}

The aim of this paper is to favor a deeper understanding of the dynamics underlying deviant behavior management. The dynamics of enactment especially seems to be overlooked in the literature. Research work have claimed the existence and pervasiveness of deviant, aberrant, dysfunctional behaviors (see Harris and Reynolds, 2003), in order to discredit the strong belief in the client sovereignty. In doing so, they assume an objective border 
between the two categories of functional and dysfunctional behavior.

But, how clear is the difference between deviant and conforming behavior for service organizations? Which criteria should they take into account? And even if it is taken for granted that there can be a clear difference between deviant and conformist behavior, how do organizations manage to make the difference clear? No answer has been found to such questions. Research may have shown the need to define categories of deviant behavior, however the categorization should not be considered as unproblematic in service organizations.

In this article, we aim to shed some light on the enactment (Weick, 2001) of deviant behavior. The point is to give a taste of the variety of possible categories for organizations, and to describe the way actors deal with this variety by making sense of encountered behavior. As the reader may have noticed, the stance owes much to interactionist sociologists who worked on deviance, among whom Howard Becker and his labeling theory (Becker, 1963) and Erwing Goffman (Goffman, 1963) stand out.

Our first purpose is to clearly demonstrate the variety and the processual nature of the deviant behavior category. The second one is to identify some organizational dilemmas during this process.

\section{An interactionnist approach to fare evasion: control interactions}

To address our general question in a specific way, we have chosen a certain type of deviant behavior (fare evasion) and a specific approach to the management of this behavior (control interactions).

Fare evasion belongs to the broader category of fraud, which is not well known as a type of deviant behavior. We found very little recent research dealing with fraud in service settings (among which: Kekre et alii 2009; Ratcliffe, 2008; Reynolds and Harris, 2005). Nevertheless, in the typology of consumer behavior proposed by Moschis and Cox (1989), it would be classified as "regulated" and "deviant". Focusing on fraudulent behaviors is then very likely to enhance the reaction of service companies.

Moreover, fraud is intrinsically related to a given customer's will to abide by fare rules or not. This means that the characteristics of a fraudulent behavior are not transparent. In particular, it is indeed difficult to tell fraud from mistake. For an organization to decide whether a customer is or is not an evader then seems to be problematic: did she/he really want to breach the rule?

That is why our approach to fare evasion management will specifically concentrate on control. By control we mean the actions of frontline employees to make sure customers abide by service rules. As Fineman and Sturdy (1999) have stated for environmental regulatory inspectors, control is very subtle and dynamic. In particular, it puts the dynamics of sensemaking in the foreground, since it requires inspectors to "create meanings" (Ibid.).

Peccei and Rosenthal (2004) have already shown client categorization by frontline employees. Employees in charge of checking focus more on problem customers. They are supposed to identify, define and react to fraudulent encountered behaviors. By accounting for the mindful practices of contact employees (Engeström and Middleton, 1998), we attempt to underline the creation of meaning in inspection work.

Thus, our purpose is to show how deviant behavior enactment is processed during control interactions. We will rely on ethnography to provide the reader with richly-grounded data so as to let him examine his beliefs (Golden-Biddle and Locke, 1993): can we accept an objective view of dysfunctional behavior or should we consider a more social-constructive approach to them? 


\section{An ethnography of bus control work}

We propose to account for contact employees' mindful practices through a description of bus inspection work. We firstly introduce the context of our field research: fare evasion management by a French bus public transportation. Then we explain how we collected the data.

\section{Control work by urban bus transportation organizations}

In France ${ }^{2}$, most of urban transport operators face a high fare evasion rate. This has dramatically increased since the 1970 s, and for many fare evaders, fraud is now no longer viewed as rule-breaking (Roché, 2003). This rise is essentially due to the rising need for mobility and to the subsequent generalization of a travelcard system (like in the UK for instance, see White, 1984). Since the 1980s, self-service has become the rule: people board the bus, show their card to the driver or get it datestamped, and get transported.

The purpose of this evolution was to improve service quality. It enabled operators to transport more people more rapidly. However, they have lost control over the bus accessibility. Therefore, they are now more exposed to the urban environment, and then, more affected by the consequences of social issues such as violence, antisocial behaviors... and fraud (Le Breton, 2001). This has resulted in a contradictory situation where the management requires improved customer orientation and service quality, whereas frontline employees encounter difficulties and "problem customers" when delivering service (Le Breton, 1999).

Most of the transportation companies try to curb fare evasion, mainly for financial

\footnotetext{
2 Since our argument relies on an ethnographic study, we deliberately focus on a given context, which happens to be the French one. Comparative studies would nevertheless be of great interest.
}

reasons: the cost can be high! ${ }^{3}$ They use many techniques, among which: poster communication, school visits to educate children, price and rules setting, etc.

The most usual process by public transport operators however remains ticket inspections. Ticket inspectors are specialized frontline employees. They are in charge of checking if passengers comply with the rules or not. Distinct penal status entitled them to gather personal information about passengers and to report if they have not abided by fare rules, whereas the company's other employees are only allowed to ask passengers for their tickets.

\section{Methodology}

The data was collected at the occasion of a ten months internship (between April 2003 and February 2004) at the Cergy-Pontoise operator, STIVO (Société des Transports Interurbains $\mathrm{du}$ Val d'Oise). The management asked the author to produce a typology of evasion and evaders on the network. A statistical analysis of fine records was carried out; some fare evaders were interviewed too; and the inspection work was observed. Given the purpose of the study, we will turn to these observations.

The author's long presence within the company actually gave him the opportunity and the time to access to the work of bus inspectors, and thus, to the way fraud was produced. We distinguish two moments of presence in the field, respectively the exploration and the confirmation stage of the study.

\section{A first approach to the inspection}

\footnotetext{
${ }^{3}$ The reader may keep in mind that the situation can be very different from one organization to another: whether it is public or not, whether it is able to precisely measure fare evasion, the financial argument is more or less strong from the point of view of the management. On the average, it nevertheless is the main reason why public transport organizations fight against fraud.
} 
In a first stage, the author directly observed control work for 2 weeks. The inspection staff introduced him as a student to the team. Though welcomed by the agents, work shadowing (Fineman and Sturdy, 1999) was not easy: inspectors work in public spaces (streets and buses) and people are very suspicious of them. As soon as people noticed a person who seemed to be with the group of inspectors, they treated this person as an inspector. The author's direct observation was thus more or less participative, and he easily adopted the inspectors' point of view. It was all the more so, as inspectors were very friendly to him, telling him their "tricks" and their "best" fare evasion stories.

These two weeks observation gave the author a first approach to the inspection work. He had learned enough about it to outline the framework of a control encounter and the usual course of this type of interaction. This guideline for further and deeper observation was tested by presenting it to the inspection manager and to two different inspectors. They mostly agreed to the description and suggested to make some corrections.

\section{Ethnography of inspection work}

In a second stage the author deepened his observation through an ethnography (Barley, 1990) of inspection work. Being appointed to inspection, he had then the occasion to become a real member of the group of inspectors. His managers and colleagues already knew him for his previous work and observations. They considered his arrival as the logical next step, since he would really see how "things were going on in the field".

As he participated in inspection work for 3 months, he actually could experience the activities directly related to inspection (checking, reporting, and even training), the relationships to the management, the bus drivers and his colleagues (lunchtimes, parties, etc.). Within 3 months, he grew familiar with control work.
This helped him to understand better the way inspectors think about fare evasion management. As a recent member of the team, he had much to learn. This means he received much advice by managers or senior inspectors: where and how he should stand in the bus, which words should be avoided when talking to "his clients" (inspectors call fare evaders so); how they may interpret this situation; the kind of details he has to pay attention to; etc.

These informal and frequent talks were very helpful; they helped him to understand inspection work the way inspectors did. For instance, on one occasion, the team manager decided to let an evader go, which the author would not have done. And as he explained the reasons of his decisions, the author got insights into how inspectors categorize people, how they decide who is trustable according to their clothes or the way they talked.

The author tried to record as many observations as possible. It was very difficult to record real interactions, given the conflict situations faced. For the same reasons, it was not possible to take photos of the setting. To keep traces of the observations the author used a day-to-day journal. After every workday, he wrote down all the remarkable events he remembered: what he had learned, the noticeable interactions he witnessed, the feelings he experienced, how his colleagues behaved, and so on.

As the three months went by, he had much less to write, which was the sign that he had become a member (in the ethnomethodological sense of the term, see (Garfinkel, 1967)): he had come to know how inspectors organize their experience. Therefore the collection of data was over.

\section{The analysis of data}

The journal provided us with a considerable amount of data. But much of it was too anecdotal and unstructured to help us to reach the aim of the study. 
We needed first a framework to organize the data. Given the purpose of the article, we turned to Goffman's dramaturgical approach to social life (Goffman, 1969; 1974). The sociologist presents some similarities with Weick, in particular a common interest in accounting for the structuring or organizing "the events and experiences of everyday life" (Czarniawska, 2006). By paying attention to the clues actors see, the frames they use and how they define situations throughout everyday interactions, Goffman gave us the conceptual tools to organize our field observations.

With the dramaturgical perspective, we then analyzed the data by comparing different workdays and interactions. Distinct stages in the control process, recurring reactions of comparable situations, common categories of fare evaders, important clues used by inspectors, etc., progressively appeared. This enabled us to reveal the different categories of fare evaders inspectors figure out, on the one hand, and on the other hand to sketch the process through which inspectors make sense of and eventually enact the behaviors encountered, and the dilemma they face to do so.

\section{The process and dilemmas of fraud control}

We now present the results of our observations. We start by introducing some categories of fare evaders shared among the inspectors. We then describe the process throughout which inspectors enact the behaviors encountered. And we finally outline three dilemma inspectors have to face during control interactions.

\section{Inspectors' categories of evasion behaviors}

Inspectors do not have anything like a formal system of categories of fare evasion behaviors. But they usually talk about their interactions, trying to explain what happened during control interactions and what kind of a situation they were in ("Have you seen how disrespectful he was to me?").

By telling their stories to each other (for instance: "Do you remember the guy that told us he didn't have to show his ticket because he worked at...?"), they shape and share categories of evaders, which they often use in other interactions to frame the situation. That is why we present them as our first results, formalized in the table below (see Figure 1)

\section{The control process}

Although we account for existing and shared categories of evaders among the inspectors, the reader may ask: where do these categories stem from? And how can an inspector be sure whether a passenger belongs to one of these categories? Actually, our observations also show that control work requires to make sense and to enact the behaviors encountered. We now describe the process of this enactment.

\section{First stage: the detection of offenders}

A control interaction, as it generally takes place $^{4}$, can be described in three stages, as follows. The first step is to distinguish between passengers who have their tickets in order and those that don't. An inspection team (3 to 5 agents) approaches a bus. Inspectors either surround it as it stops, first check people getting off the bus, then board the bus and check the other passengers; or they can get on the bus at a bus stop, and check passengers within the bus as it moves along.

\footnotetext{
${ }^{4}$ Despite some differences from one network to another, like the team size for instance, there is a strong similarity among different transportation systems: legal frame and tacit rules (among which moral ones); physical frame of the transportation system (public space, station, bus design...), payment (fare and tickets design).
} 
Figure 1 Inspectors' categories of evaders

\begin{tabular}{|c|c|}
\hline People who have no choice & $\begin{array}{l}\text { People that can not afford the ticket's price, but they need to take the bus } \\
\text { however (for instance: unemployed people going to a job interview) }\end{array}$ \\
\hline Gamblers & $\begin{array}{l}\text { People who know they are not likely to meet inspectors. They have a } \\
\text { probabilistic view of evasion and consider this behavior as economically } \\
\text { rational. When they meet inspectors, they are often prepared to pay the } \\
\text { fine on the spot and do not even try to escape. }\end{array}$ \\
\hline Ideological opponents & $\begin{array}{l}\text { People challenging the legitimacy of control. Many of them say they } \\
\text { "hate" inspectors, in particular young people who can be violent }\end{array}$ \\
\hline Dissatisfied clients & $\begin{array}{l}\text { People protesting against poor service quality by not buying a ticket or } \\
\text { refusing to show their card to the inspectors }\end{array}$ \\
\hline Cheats & $\begin{array}{l}\text { People pretending to play by the rules, but they will never receive the fine } \\
\text { because their ID card is faked or it shows and old address }\end{array}$ \\
\hline People who have no clue & $\begin{array}{l}\text { Elderly people or children most of the time, who have difficulties in taking } \\
\text { the bus, for instance because they don't know the tarification system }\end{array}$ \\
\hline
\end{tabular}

As inspectors check passengers' tickets, they establish a first contact with passengers. At this moment, inspectors especially deal with rows of anonymous people. When the passenger's ticket is in order, the communication is usually very brief. With the great majority of passengers, the interaction consists in exchanging a few words. Inspectors announce the control ("Ladies and gentlemen, we are going to check your tickets, show your tickets, please") and assure a minimum level of civility in the encounters ("Thank you" "Have a good day"...). Passengers most often do not say a word.

The first stage ends when inspectors trace a border between the two kinds of passengers. They usually do so by saying "your ticket is not valid, sir!" and "please go to the back of the bus." As soon as they have pronounced these words, inspectors focus on the offenders. The encounters then progress very differently.

Second stage: the negotiation of a minimal definition of the situation

The purpose of this second stage of control is actually very different from the ticket checking. The aim of the agents is then to settle a relationship guaranteeing the progress of the interaction. At this time they do not know yet how they are going to react to the situation encountered. In some cases actually, the outcome of the interaction is not a fine.

For this reason, the second stage of control is merely a negotiation about the definition of the situation: did the offender mean to evade? If he did not, then what are the causes of his mistake? Are these causes legitimate? For instance, inspectors think homeless people should not be reported. They are more indulgent with young children or elderly people as well.

Offenders often play an active role in defining the situation. They react in very unpredictable and different ways. Some of them challenge the very principle of checking, whereas, for instance, an offender lady said on one occasion: " $O f$ course I deserve a fine. I am a former schoolteacher and I have taught children for years that it is not good: Then I mustn't do it either."

So in a more or less conflicting interaction, the inspector and the offender argue to reach an agreement on the situation. Sometimes it is found very easily, but in other cases the inspector has to resort on persuasion. Of course, inspectors have at their disposal coercive tools to constrain the offender, especially the possibility to request the presence of a police officer with greater powers, for instance that of taking an offender to the police station. But inspectors do not automatically call for the police; they hesitate to do so and seldom 
do. This is one of the inspection dilemmas, which we will further develop below.

In intermediary cases, inspectors rather try to convince the offender (and the people around who witness the interaction) by reframing the situation. They might obviously suggest a legal frame of analysis ("your behavior is an offense"), but observation shows it is not very efficient; most of the time, inspectors do not even mention legal rules. On the contrary, they refer quite frequently to other deviant behaviors.

A very successful comparison used by inspectors is that of the baker: "When you go to the baker's, you pay for your bread. It is the same for bus transport." "This approach does not focus directly on the rule breaking, but rather on the definition of the transport situation: what does being transported mean? What can it be related to?

Inspectors make these efforts to come to an acceptable definition of the situation both for the inspector and for the offender. The point is precisely not to tell the offender she/he is a fare evader. This could lead to a rejection of inspection by offenders, and even to violent conflicts. By working on the definition of the situation, inspectors precisely try to avoid such outcomes, which favor a high rate of work accidents.

This critical and sometimes minutes-long stage is the moment when the inspector negotiates the definition of the situation with two purposes. Firstly, to avoid a deadlocked interaction, like: 'You're sticking to your guns, I'm sticking to mine". Secondly, to better qualify the offense detected, so as to choose the appropriate solution: to call for the police, to report, to moralize or to let go

\footnotetext{
5 The reader may notice the parallel is not an accident: there is a parallel regarding the type of economic good (bread and transport are both consuming "products"); and the type of obligations between the producer and the consumer (in both cases, there is no written and negotiated contract, but a conventional way to contract).
}

(inspectors call this "letting him/her off the hook").

Third stage: the outcome of the interaction If the inspector has decided to call for the police or to let go, the control interaction has been brought to an end. It goes on, only if reporting is at stake. As soon as they judge that the common definition of the situation enables them to report, they enter the third stage, which is signaled by getting off the bus with the offender. Inspectors are never sure the offender is not lying, or pretending to agree. It can even happen that an offender gets off the bus with the inspector as if he is going to cooperate, but runs as soon as he set foot on the pavement!

That is why the inspector usually remains suspicious. Nevertheless, compared to the previous stage, this one essentially seems to be a matter of form. It mainly consists in gathering information about the offender's identity, in order to give him a fine. The inspector asks the offender for his name, address, date of birth, etc. and writes down the bus line number, the time of the check, the kind of offense, etc. in his book.

At the same time in fact, the inspector keeps on making sense of the offender's behavior. It shows that not only the offense is at stake. The inspector pays attention to the reactions of the offender throughout the interaction. These signs help him define the behavior of the passenger and choose the better solution. In particular, inspectors usually take into account the reaction of the offender to the control: did she/he challenge it or not? And if not, did the offender cooperate and give the information the inspector asked for? Was he abusive or did he adopt a contemptuous attitude towards the inspectors?

At the end of the interaction, this can influence the outcome, and inspectors often finally decide to let off a passenger, because he/she adopted a compliant and / or pleasant attitude towards the inspection team. When asked, the agents justify this practice: it is not just about being "nice to 
people", the point is that such an outcome is likely to be more effective than reporting the offense. They hope that this passenger will have his ticket in order when checked the next time. The criteria for deciding whether reporting is the best solution are very subtle, and inspectors do not always agree with each other. This is another dilemma raised by control that will be further analyzed below.

However, whatever the decision the agent makes, the control interaction has come to an end. And more important, he has completed his conclusions regarding the passenger's behavior. Be it a fine or clemency, getting to the outcome of the control interaction has enabled the inspector to carry out the enactment of the deviant behavior.

\section{The dilemmas of control}

Observing the control work also revealed three dilemmas for inspectors. We present them as complements to foster better understanding of the organizational tensions within the enactment process we have described.

\section{Outcome visibility / Outcome efficiency}

Generally, inspectors can appreciate the relevance of reporting on their own. For instance, as we mentioned, homeless people are hardly ever reported, because inspectors know it is useless to pursue them (they do not have any address...). Inspectors are often clement with elderly people too, because of their age, although their behavior is as much an offense as that of other people.

However, inspectors are expected to deliver fines. That is, the management wants them to produce a given number of fines every workday. At STIVO, there is no formal individual objective, but the management put some pressure on the inspectors by checking their fines production - and expressing dissatisfaction if they judge it insufficient. The management also expresses the notion of fine "quality", which means that effective payment by the fare evader is taken into account and expected, be it on the spot or later (by sending a check for instance).

This pressure for production is a strong limitation to their decision autonomy, which is nevertheless real. From the inspectors' point of view, this results in a tension within inspection work, between the efficiency of the outcome (is a fine the best way to solve the present situation?) and the outcome visibility (have I handed out enough fines to please the management?). This tension plays a role in the decision the inspector is going to make, and thus, it influences fare evasion enactment.

\section{Offense focused perspective / dysfunctional behavior management perspective}

As mentioned in the third stage of the process, inspectors often decide not to report when an interaction has gone well. Sometimes they decide to report it, but give the offender a smaller fine. There are two reasons for such decisions. In the first case, the offender has suggested a definition of the situation that convinced the inspector not to report on him. The rule-breaking is legitimate.

For instance, let us take the case of an offender, who had already been reported the same day and was on his way home: many inspectors would claim he does not deserve a fine. But other agents will contest the decision to let him off. They generally argue that the offense has to be punished, and that the inspection work is precisely to detect free-rider behaviors and to show they are not accepted by the operator. These inspectors focus on the present situation. They believe it is more important to show the presence of the bus company.

For some agents it is clear that control success is a long term process. They suggest a broader view of inspection: it is not just a matter of detecting and reporting. According to them, it is indeed part of a policy to reduce the fraud rate. This means 
at least two things. Firstly, checking should be thought and organized on the long term and inspectors should pay as much attention to the future passengers' behavior as to the present offense. And secondly, it may not only take into account the occurrence of rule breaking, but also the offender's behavior during the interaction. In their view, if the offender escapes the fine but has shown respect for the inspection and buys tickets for his next trips (and even better: a travel card!), the gains largely exceed the costs for the company.

\section{Service / sanction}

Another dilemma is that between service and sanction. It is well illustrated by the possibility to call for the police. As we mentioned, inspectors hesitate to call for a police officer. With the powers of police officers being more extended, they are able to re-enforce the inspectors' action. The coercive assistance of police should then help the inspectors.

Why do they limit their call to the extreme cases? One of the reasons is obvious: police officers have other priorities. If inspectors request them too frequently and without strong motives, they might grow tired of it and decide not to come systematically. Indeed, when inspectors decide to call for the police, they never know how long they will have to wait. And this is precisely the second reason why they were reluctant to do so.

In fact, as long as inspectors wait for the police officer to come, they wait on the bus. Otherwise, the offender could escape. And even when the police is on the bus, their intervention is actually timeconsuming. Paradoxically, requesting the police to make the inspection easier often goes against the very intent of a transportation system: it produces immobility!

Our point is not to make a choice between passengers' fraud and bus immobility: it is rather to underline a fundamental tension within the inspection activity. Sanctioning often acts in opposition to the delivery of a quality service. This tension can be illustrated by the first stage of the process: most people do not like inspectors and blame them for checking tickets when passengers get off the bus: in their view, anyway, it is obvious that they are not in breach of the law. As a consequence, customers think inspectors are useless and have a negative impact on service quality.

\section{Implications and conclusion}

This study aimed at demonstrating the organizational and processual nature of the dysfunctional behavior category. It clearly showed that deviant behavior is not transparent for an organization, that it has to be given significance. The suggested perspective was that of enactment and sensemaking.

This study addressed an issue which is given no attention in the dysfunctional behavior literature. As a consequence, it is exploratory and it mainly brings insights into dysfunctional behavior management. We will successively come back to the main results, outline the managerial implications and underline the limitations of the study and avenues for further research.

\section{Results' discussion}

There are three main results in the study. First, contrary to what the existing literature on deviant customer behavior seems to assume, the distinction between deviant / conform, or functional / dysfunctional behavior is not clear. Making sense of certain behaviors, in this particular case fare evasion, can be problematic for organizations, particularly in service encounters.

This is why, as a second result, actors within organizations work on the meaning of the behaviors encountered. The case of bus inspectors has shown how specialized frontline employees enact deviant behavior because they need to react to these behaviors and to make sense of them. 
Their work processes the deviant behavior category which becomes more precise and more meaningful.

The third result of the study deals with organization. Actually, service quality as well as contact employee management appears to play a critical role in the way dysfunctional behaviors are enacted. Inspection work witnesses strong tensions, between short- or long-term, control or service, visibility or efficiency objectives. There is no a priori harmonious dysfunctional behavior management.

This last result makes clear the very purpose of this study. Revealing the processual nature of dysfunctional behavior is not just a matter of science: organizations and therefore managers have to care about the enactment of deviant behavior because it may cause organizational tensions and negative results.

Indeed, our observations show how insufficient attention to the way inspectors solve their dilemma can lead to bad consequences regarding client satisfaction, customer skills, or fare evasion rate. This has in turn implications for financial results of the companies. That is why we put the stress on some organizational principles our results lead to.

\section{Managerial implications}

"Treating enactment seriously also implies that if we are going to talk to practicing managers, we should talk to them in terms of understanding how their actions and non-actions are the sources of the actual realities they face" (Gioia, 2006). Here is the point: how could managers organize service delivery so as to effectively shape clients' dysfunctional behaviors?

The article brings three main managerial implications about the management of deviant behavior. Firstly, since deviant behaviors are not just a simple issue managers must be aware of, but a complex phenomenon requiring investigation, they have to keep asking questions about their clients' behavior.
The directions for investigation are numerous: which objectives are appropriate regarding clients' behavior? Does the company tolerate certain deviant behavior? How does it react to them? Are there some contradictions between service and control objectives? Have the agents encountered some new behavior? Can our deviant customers be turned into regular clients? Etc. The answers to these questions must be articulated together in a coherent client management policy.

The second implication is related to these numerous questions the manager has to ask. To answer to them, he should design a process-oriented organization that can favor collective investigation. The purpose of such an organization is not to provide for definitive solutions and inflexible procedures about client behavior. It is to be able to react to a changing environment and to become conscious of the way the company contributes to create this environment.

To regulate the continuous interaction between a company and its environment, a manager should pay attention to every kind of actor involved in client behavior management (quality managers, frontline employees, specialized or not, operation managers, marketing experts, etc.). $\mathrm{He}$ should consider their different perspectives on the topic and how their respective work contributes to the enactment of the clients' behavior.

Consistent discussion and collective reflection are essential to improve the organization's ability to make sense of its environment. Here the manager mainly plays a leading role in the meetings; he has to facilitate vertical contacts (between the management and the "field") as well as horizontal contacts (between different services, for instance: operation management and marketing, or bus drivers and inspectors).

The third recommendation deals with frontline employees' management. Their work appears to be critical, and they should therefore be given sufficient 
attention - especially those involved in control tasks. It is no news for service professionals (scholars or managers) that frontline work is simultaneously characterized by a high discretional power (Lipsky, 1983), empowerment (Harltine and Ferrel, 1996), and role conflicts (Hartline and Ferrel, 2000). Our study brings evidence that this applies to inspectors too. For urban transport especially, where frontline employees are critical for the clients' perception of service quality (Friman and Edvardsson, 2003), the inspectors undergo a high level of tension between service and sanction (or even control).

As a consequence, we stand for a double role for the manager regarding contactemployees. The first one consists in backing up the agents by helping them to better their practices and giving them some clues to solve their dilemma. Actiontraining, mentoring and team debriefings should be considered as management levers for contact employees. The second role is about listening to the agents and systematically accounting for their perspective and knowledge. They are privileged witnesses in the field, and as such, they can learn much to the management about the contradictions of the company policy or the evolutions of the customers' behaviors they witness.

\section{Limitations and research avenues}

Finally, we would like to make some distinctions in order to discuss how far the reader can rely on our field description. Is the case of fare evasion representative of every dysfunctional behavior? We suggest an answer focusing on the type of service organizations.

Is fare evasion similar to not paying one's bill at the restaurant? Or is transport fraud equivalent to credit card fraud? On the one hand, we have to admit that fare evasion is precisely a very difficult behavior to cope with, because it intrinsically is dissimulation. For instance, a bus driver being insulted may not hesitate as long as the inspectors on the meaning of the behavior.

On the other hand however, in line with our enactment approach to deviant behavior, what makes a difference is rather the service setting or the service delivery organization. Coming back to the example of credit card fraud, we note that it is very likely to happen on the internet, because it is characterized by a "lack face-to-face interactions with the fraudster" (Barker and al., 2008). In the same way, the role of merchants facing customers appears critical: "it is imperative that merchants become familiar with the characteristics present during fraudulent transactions since they are in contact with the perpetrator at the point-of-sale" (Ibid.).

Not paying one's bill at the restaurant could be very difficult indeed in a fast food where you have to pay before you can eat. At the opposite, in a luxury restaurant emphasizing the hedonic dimension of service ( $\mathrm{Ng}$ and al., 2007), the head-waiter has to be tactful if he suspects a customer is about to leave without paying! In such a situation, the frontline employee is likely to face the same dilemma as the ticket inspector to make sense of the client's behavior and to cope with it.

This brief comparison between three types of deviant behavior actually shows that the enactment perspective is not limited to certain kind of behavior, even if some seem to be more mysterious than others. The interest of such a perspective rather depends on the kind of service a company delivers, and how it delivers it. Mass services and quality focused services may stand first-rank.

A serious comparison is beyond the scope of this article, so we call for further research work deepening the confrontation between different types of behaviors and different types of service. This work should focus on other dysfunctional behaviors and on other service activity (for instance individual and hedonic services like theme park). 
It would also be of great interest to deepen our understanding of control activities. The existing literature on deviant behavior has not paid much attention to this kind of activity, although it seems fundamental for this managerial issue.

And last but not least, there is no reason the enactment perspective should be restrained to the front office. Although we have chosen to focus on frontline employees first, where the enactment of dysfunctional behavior is the most obvious, the process is very likely to involve the entire organization: for instance, to what extent do advertising activities participate in enacting dysfunctional behaviors?

It is another argument to hope for more research on the intriguing issues raised by the deviant behaviors enactment approach.

\section{References}

Barley, S. R. (1990), "Images of imaging: notes on doing longitudinal field work", Organization science, Vol. 1 No. 3, pp. 220-247.

Barker, K. J., d'Amato, J. and Sheridon, P. (2008), "Credit card fraud: awareness and prevention", Journal of financial crime, Vol. 15 No. 4, pp. 398-410.

Bateson, J. E. G. (1985), "Perceived control and the service encounters", in Czepiel, Solomon, M. and C., Surprenant, C., The service encounter: managing employee / customer interaction in service business, Lexigton Books, New-York, NY, pp. 67-82.

Becker, H. S. (1963), Outsiders: studies in the sociology of deviance, Free Press of Glencoe, London.

Bittner, M.-J., Booms, B. H. and Mohr, L. A. (1994), "Critical service encounters: the employees' viewpoint", Journal of marketing, Vol. 58 No. 4, pp. 95-106.

Cox, D., Cox A. D. and Moschis, G. P. (1990), "When consumer behavior goes bad: an investigation of adolescent shoplifting", Journal of consumer research, Vol. 17, pp. 149-159.

Czarniawska, B. (2006), "A golden braid: Allport, Goffman, Weick", Organization studies, Vol. 27 No. 11, pp. 1661-1674.

Engeström, Y. and Middleton, D. (1998), "Studying work as mindful practice", in Engeström, Y. and Middleton, D., Cognition and communication at work, Cambridge University Press, Cambridge, pp. 1-14.

Fineman, S. and Sturdy, A. (1999), "The emotions of control: a qualitative exploration of environmental regulation", Human relations, Vol. 52 No. 5, pp. 631663.

Friman, M. and Edvardsson B. (2003), “A content analysis of complaints and compliments", Managing service quality, Vol. 13 No. 1, pp. 20-26.

Fullerton, R. and Punj, G. (2004), "Repercussions of promoting an ideology of consumption: consumer misbehavior", Journal of business research, Vol. 57 No. 11, pp. 1239-1249.

Fullerton, R. and Punj, G. (1997), "Can consumer misbehavior be controlled? A critical analysis of two major control techniques", Advances in consumer research, Vol. 24 No. 1, pp. 340-344.

Fullerton, R. and Punj, G. (1993), "Choosing to misbehave: a structural model of aberrant consumer behaviour", Advances in consumer research, Vol. 20 No. 1, pp. 570-574.

Garfinkel, H. (1967), Studies in Ethnomethodology, Prentice-Hall Inc., Englewood Cliffs, New Jersey.

Gioia, D. A. (2006), "On Weick: an appreciation", Organization studies, Vol. 27 No. 11, pp. 1709-1721.

Goffman, E. (1974), Frame analysis: an essay on the organization of experience, Harper \& Row, New York, NY. 
Goffman, E. (1963), Stigma, Prentice-Hall, Englewood Cliffs, New Jersey.

Goffman E. (1959), The presentation of self in everyday life, Anchor Books, New York, NY.

Golden-Biddle, K. and Locke, K. (1993), "Appealing work: an investigation of how ethnographic texts convince", Organization science, Vol. 4 No. 4, pp. 595-616.

Harris, L. C. and Reynolds, K. L., (2004), "Jaycustomer behavior: an exploration of types and motives in the hospitality industry", Journal of services marketing, Vol. 18 No. 5, pp. 339-357.

Harris, L. C. and Reynolds, K. L., (2003), "The consequences of dysfunctional customer behvior", Journal of service research, Vol. 6 No. 2, pp. 144-161.

Hartline, M. and Ferrel, O. (2000), "Corridors of Influence in the Dissemination of Customer-Oriented Strategy to Customer Contact Service Employees", Journal of Marketing, Vol. 64 No. 2, p. 35-50.

Hartline, M. and Ferrel, O. (1996), "The Management of Customer-Contact Service Employees: An Empirical Investigation", Journal of Marketing, Vol. 60 No. 4, pp. 52-70.

Kekre, S., Secomandi, N., Sönmez, E. and West, K. (2009), "Balancing risk and efficiency at a major commercial bank", Manufacturing \& service operations management, Vol. 11 No. 1, pp. 160-173.

Le Breton, E. (2001), "Les compromis fragiles du traitement des conflits publics dans les transports urbains", Sociologie $d u$ travail, Vol. 43 No. 4, pp. 515-531.

Le Breton, E. (1999), "L'utilisateur des transports collectifs urbains: une identité en débat au sein des entreprises", Sociologie du travail, Vol. 41 No. 3, pp. 255-273.

Mason, K. and Harris, L. C. (2005), "Pitfalls in evaluating market orientation: an exploration of executives' interpretations", Long Range Planning, Vol. 38, pp. 373-391.

Moschis, G. P. and Cox D. (1989), "Deviant consumer behavior", Advances in consumer research, Vol. 16, pp. 732-737.

Lipsky, M. (1983), Street-level Bureaucracy: dilemmas of the individuals in public services, Russel Sage Foundation.

Lovelock, C. (1994), Product Plus: How product + service $=$ competitive advantage, McGra-Hill, New York, NY.

Ng, S., Russel-Bennet, R. and Dagger, T. (2007), "A typology of mass services: the role of service delivery and consumption purpose in classifying service experiences", Journal of services marketing, Vol. 21 No. 7, pp. 471-480.

Peccei, R. and Rosenthal, P. (2000), "Front-line responses to customer orientation programmes: a theoretical and empirical analysis", International Journal of Human Resource Management, Vol. 11 No. 3, pp. 562-590.

Ratcliffe, C., McKernan, S.-M. and Finegold, K. (2008), "Effects of food stamps and TANF policies on food stamp receipt", Social service review, Vol. 82 No. 2, pp. 291-334.

Reynolds, K. L. and Harris, L. C. (2006), "Deviant customer behavior: an exploration of frontline employee tactics", Journal of marketing theory and practice, Vol. 14 No. 2, pp. 95-111.

Reynolds, K. L. and Harris, L. C. (2005), "When service failure is not service failure: an exploration of the forms and motives of "illegitimate" customer complaining", Journal of services marketing, Vol. 19 No. 5, pp. 312-335.

Roché, S. (2003), «D’un point de vue sociologique: «frauder est un comportement conforme »», Transport Public, mars 2003.

Rosenthal, P. and Peccei, R. (2006), "The social construction of clients by service 
agents in reformed welfare administration", Human Relations, Vol. 59 No. 12, pp. 1633-1658.

Rosenthal, P. (2004), "Management control as an employee resource: the case of front-line service workers", Journal of management studies, Vol. 41 No. 4, p. 601.

Schneider, B. and McFarlin, D. (2004), "Welcome to the world of service management", The academy of management executive, Vol. 18 No. 2, pp. 144-150.

Weick, K. (2001), Making sense of the organization, Blackwell Publishing, Oxford, UK.

White, P. R. (1984), "Development of the "travelcard" concept in urban public transport", Service industries journal, Vol. 4 No. 3, pp. 133-150. 